\title{
Digital ethnography of social media: Srikandi Sungai Indonesia activists in water and river conservation
}

\section{Etnografi digital media sosial: Aktivis Srikandi Sungai Indonesia dalam konservasi air dan sungai}

\author{
Sri Kusumo Habsari ${ }^{1 *}$, Fatkhu Rohmatin ${ }^{2}$, \& Istadiyantha Istadiyantha $^{3}$ \\ ${ }^{1}$ Department of English, Faculty of Cultural Science, Universitas Sebelas Maret \\ ${ }^{2}$ Department of Cultural Studies, Faculty of Cultural Science, Universitas Sebelas Maret \\ ${ }^{3}$ Department of Indonesian, Faculty of Cultural Science, Universitas Sebelas Maret \\ Address: 1,2,3 Jalan Ir. Sutami 36A Kentingan, Surakarta, Central Java, Indonesia 57126 \\ E-mail: skhabsari@staff.uns.ac.id, fatkhurohmatin2@student.uns.ac.id, \\ \& istadiyantha@staff.uns.ac.id
}

Article History: Received 9 March 2020; Accepted 7 January 2021; Published Online 5 February 2021

\begin{abstract}
Women have been recognized as environmental activists and having a greater awareness of ecology worldwide since the $19^{\text {th }}$ century. There are many stories of women activists worldwide who have developed significant models for protecting the environment. Social media's popularity has changed how activists advocate their ideas to generate awareness and environmental protection participation. This study focuses on the grassroots women who join SSI and actively campaign for water and river conservation through social media. It attempts to identify how they use social media to campaign and analyzes their posts' digital contents to understand their motivation for challenging the water river degradation and their value systems and insights, which drive them to take action. This study considers social media as cultural artifacts and providing spaces for social interaction. The researchers observe SSI's posting behaviors and identify how they use social media for environmental activism to obtain the data. The finding shows two kinds of women activists join SSI: those who actively involve and participate in the campaign and those who click to support the activities. It also shows that the environmental activist women use social media to communicate their activities rather than maximizing its function to campaign to change the public perspective and attitude concerning the need to take care of the rivers' water and riverbanks. Women activists continue to adopt dominant Indonesian patterns and social media use orders. Social media's function is still seen only as a space for selfies rather than to develop a political message concerning environmentalism.
\end{abstract}

Keywords: Srikandi Sungai Indonesia; women environmental activist; digital activism; social media; digital ethnography

\begin{abstract}
Abstrak
Perempuan telah diakui sebagai aktivis lingkungan dan memiliki kesadaran yang lebih besar tentang ekologi di seluruh dunia sejak abad ke-19. Banyak kisah tentang aktivis perempuan di seluruh dunia yang telah mengembangkan model signifikan untuk melindungi lingkungan. Popularitas media sosial telah mengubah cara aktivis mengadvokasi ide-ide mereka untuk menghasilkan kesadaran dan partisipasi perlindungan lingkungan. Studi ini berfokus pada perempuan akar rumput yang bergabung dengan SSI dan secara aktif berkampanye untuk konservasi air dan sungai melalui media sosial. Studi ini berusaha untuk mengidentifikasi bagaimana mereka menggunakan media sosial untuk berkampanye dan menganalisis konten digital yang diposting untuk memahami motivasi menantang degradasi sungai air dan sistem nilai serta mengetahui wawasan yang mendorong untuk mengambil tindakan. Dengan mempertimbangkan media sosial sebagai artefak budaya dan ruang untuk interaksi sosial, data diambil melalui pengamatan terhadap perilaku para aktivis yang memposting. Temuan menunjukkan bahwa ada dua jenis aktivis perempuan yang bergabung dengan SSI: mereka yang secara aktif terlibat dan berpartisipasi dalam kampanye dan mereka yang hanya mengetuk untuk mendukung kegiatan. Ini juga menunjukkan bahwa perempuan aktivis lingkungan terlihat menggunakan media sosial hanya untuk mengkomunikasikan kegiatan mereka daripada kampanye mendorong perubahan perspektif dan sikap masyarakat tentang perlunya menjaga sungai dan tepian sungai. Para aktivis perempuan masih terus mengadopsi pola dan tatanan dominan Indonesia dari penggunaan media sosial. Fungsi media sosial terlihat masih sebatas untuk swafoto daripada mengembangkan pesan politik tentang lingkungan.
\end{abstract}

Kata kunci: Srikandi Sungai Indonesia; aktivis lingkungan perempuan; aktivisme digital; media sosial; etnografi digital 


\section{Introduction}

Srikandi Sungai Indonesia, translated as Srikandi of Indonesian River (hereafter called SSI), was founded on 21 April 2016 in Jogjakarta after the first river congress in Banjarnegara, Central Java. The word Srikandi refers to the female character in the Mahabharata epic, symbolizing a woman's ability to perform in public. The community's goals are to educate society on the importance of conserving the environment, especially rivers, and developing a creative economy for women's empowerment. The members are grassroots women from various professions and backgrounds who care for the environment, especially rivers. They work together to clean rivers, encourage people not to throw their garbage into rivers, and conduct roadshows to various institutions to campaign about the importance of clean water and the environment (Sahana 2017). Meanwhile, on 12 June 2017, the Ministry of Women Empowerment and Child Protection officially opened the Srikandi of Indonesian River School, a community-based activism extension of the SSI environmental organization. SSI's primary goal is to change the society's perspective of the need to have a healthy river environment through education, campaign, training, mentoring, and the activities Srikandi of Indonesian River School are more practical. The members work jointly to clean rivers from any garbage and create healthy and child-friendly riverbanks (Pertana 2017).

Women have been recognized as environmental activists and having a greater awareness of ecology worldwide since the $19^{\text {th }}$ century. There are many stories of women activists worldwide who have developed significant models for protecting the environment. The Chipko Movement dates back to the $17^{\text {th }}$ century in India, and the Green Belt Movement, founded in 1940 in Kenya, demonstrates the grassroots women's concern for environmental issues and their belief that environmental problems are controllable through effective collective action (Zelezny \& Bailey 2006). Findings from studies of national data surveys in some countries also show that women are more concerned about environmental issues and problems, especially in their neighborhood or community (Mohai 1992). These findings lead to theoretical explanations of the correlation between environmental concern with gender expectations. Women expect to have a motherhood mentality; meanwhile, men socialized to reinforce the roles as family breadwinners. Thus, since childhood, women are socialized to develop nurturing and caring attitudes to others. When women take active roles in responding to social issues, their concerns are still around caregiving works, such as helping the needy, elderly, or homeless. The different socialization between men and women leads to different concerns and perspectives on the idea of environmentalism (Strapko et al. 2016).

Various studies show that men and women have different perspectives and reasons for involving environmental activism (Breton 1998, Zelezny et al. 2000). Although women are more concerned with environmental issues, their reasons are mostly the extension of their domestic roles, such as the health and the safety of the family. When men consider participating actively, they tend to engage with political, environmental activities that address more general environmental issues, such as acid rain or other worldwide environmental issues (Blocker \& Eckberg 1989). Activities such as attending public meetings or hearings, signing a petition, and donating money or time to the organization are engaging and conducted by both men and women (Mohai 1992). Scholarly discussion leads to a question on the women who join SSI to determine the reason for their concern about the environmental issues of the rivers in Indonesia; however, this study does not consider continuing the discussion of the gender divide on environmental activism. Instead, in correlation to the development of technology, especially incorporating digital technology into its users' everyday life, this study significantly raises questions on how women communicate their concerns on environmental issues through their social media. Badan Pusat Statistik (2018) has reported that 37.9\% of Indonesian females accessed and used social media through their smartphones in 2018.

The development of technology undoubtedly influences the structures of social and political movements (Gerbaudo 2012). Since the pre-Web 2.0, movement and activism have been beginning to consider utilizing the internet to develop their reach of information spreading and handling and organization structures. With social media development and user-friendly utilization, activists can 
foster their activism and movement and reach a broader public to encourage them to participate and develop networking and knowledge sharing. Advanced communication technology facilitates the medium for the socialization of activism and movement to a wide variety of interaction and engagement. The popularity of smartphones and almost all groups of people encourages people not to consume passively and actively involve various activism and movement, which is recognized as digital activism (Joyce 2010).

The idea of digital communication refers to the different ways of communication, interaction, and the redefinition of the public sphere. Digitalism also imposes the redefinition of social interaction, crowd and engagement, and participation through a digital network. A study on the development of virtual communities found that people's access to digital tools has initiated some people to create new groups and new communities and actively involve in political activities (Gurstein 2007). The new Information and Communication Technologies (ICTs) also bring up community activists, policy-makers, and citizens a new set of possibilities for fostering social cohesion, strengthening neighborhood ties, overcoming cultural isolation, and combating social exclusion and deprivation(Keeble \& Loader 2001).

As a consequence of the advance of Computer-Mediated Communication (CMC) technologies, the tools could link people or communities from different spaces and geography to connect and create networking (Wellman 2001). It shows that digital tools have empowered some people because of the easiness of accessing knowledge and networking. Social media as digital tools serve to create and develop digital communities. Although the community is virtual, as is the social relation, values still need to be structurally defined and designed to register the community in the public sphere with its particular intention (Stolterman 2001).

The platform through which the virtual community members communicate with each other should provide the values of interactivity and participation (Jenkins 2006), the point at which an individual's knowledge, or capacity to act, is transformed into communicative action (Lievrow 2001). The primary mode of media engagement is receptive to encourage users to involve in social and cultural participation, and the platform should accommodate users to search, share, recommend, link, and argue (Lievrouw 2011). In its relation to digital activism, the virtual community should be established with organizing principles to raise specific alarming issues and attract the public to respond and react to these. Thus, the virtual community should have an open system characteristic that could mediatize people to be creative and lead to innovation.

Every platform has its structure and values; Twitter provides a space for people to send tweets publicly seen and responded to as a digital realm. Compared to Facebook, Twitter does not need broadband internet access; however, it still posits connections to broader themes' tweets, specific individuals, or communities. Through the hashtag, Twitter enables people to link subjects, events, or associations (Murthy 2013). Twitter's facility to mediate conversations, even in impromptu interactions across an unobtrusive social network, makes this platform seem promising for the social movement. The comparable platform of Twitter is Facebook. The similarity is in its highly interactive social medium, which offers a broadly worldwide network for ordinary people. If Twitter is more like a blog emphasizing communication organization, Facebook connects and fosters friends, encouraging followers' accumulation through their public posts (Murthy 2013). As a network, Facebook features are continually developed over time to provide people's needs to manifest their moral and social distinctions and classification through their timeline, wall, status, updates, newsfeed, apps, like, and tag (Riles 2001). Facebook also provides a discussion forum that can reveal public concern about some instances from the comments they write (Dalsgaard 2016).

Instagram is a photo-sharing platform that provides a space for social relationship practices (Serafinelli 2018). The principle of Instagram is on the power of images, which could initiate users' engagement. The activities of photo sharing, events, people, and surroundings are perceived as new forms of everyday life (Serafinelli 2018). In its development, many scholars discussed that Instagram has also been used as a medium to reveal symbolic imagery to reform various societal issues. 
The popularity of the three platforms, well-known among social media platforms, attracts scholars to explore these platforms' use and comprehension for political, social, and cultural movement. Disagreements between scholars vary from approaches to look at only interactivity, participation, or feedback to approaches on observing the tactics, such as the use of the medium as content, the rejection of ideology, the merging of politics and art, and appreciation of the ability of digital information to make things happen directly (Braman 2002). Scholars are interested in researching the usage of the medium for culture jamming, alternative computing, participatory journalism, mediated mobilization, and shared knowledge (Lievrouw 2011).

With social media's function as mediated mobilization, activists take advantage of the platforms to advocate their ideas to generate awareness and participation for environmental protection. Social media offers a space for social networking with varying content-generating, sorting, filtering, and distribution user functions (Leyva 2018). A study on Twitter has found out that this platform has been used as an organizing mechanism to drive a social movement (Segerberg \& Bennett 2011).

The activists have also recognized social media in providing value for organization or community recruitment, engagement, and campaign (Castells 2013). Other environmental movements use social media for fundraising, popularize their existence, and campaign their activities to increase the number of individuals' enrollment and engagement to various issues as communicated by the organizations (Hemmi \& Crowther 2013). They encourage people to click 'like' on their social media, follow their actions, say their voice, and join interactive conservation debates (Büscher 2014).

As the social media characteristics are open and expansive, the participants enrolling in the environmental organization can construct and show their identity, which shows their plurality rather than being galvanized by the organization (Bennet 2004). In the environmental movement, studies show that environmental non-governmental organizations have used digital technology to influence. They use digital media to spearhead a transition and sometimes to threaten conventional governance structure regarding environmental concerns and policies (Nulman \& Ozkula 2016). Some research suggests that participation in social media does not always associate with off-line practices. Digital activism can be just slacktivism because they only click "like" on the posts rather than actively campaign (Leyva 2018).

This study attempts to involve the academic discussion of the significance of social media on the environmental movement. The reason to apply the digital approach mostly derives from the difficulty of finding out the invisible world of specific people or communities in their real environment. Photography or visual works that they post in their digital world sometimes speak extensively to understand their self-identity and their power relation to the world surrounding them. In line with Van Leeuwen \& Jewitt (2004), photos are communicative, primarily when the photo-sharing is understood before and after the posting. Thus, the purpose of this study is to understand their digital dissemination of environmentalism. It focuses on observing their posting behaviors as cultural practices.

This study's locus is the ethnography of the digital or virtual world, which develops from incorporating everyday life into digital mediated practices. Digital media provides spheres for people to share their personal stories in public coined with everyday activism (Vivienne 2016). Although they are ordinary people who use media to share their stories or post their photos, they could have certain political viewpoints. They are grassroots, and the public does not recognize them as activists; however, it does not mean that they do not engage with specific political projects; this study is environmentalism. The social context they bring about is the Indonesian habit's environmental issues to pollute water and neglect to care for the natural environment. Under the locus of the digital ethnography methodological approach, this research pays specific attention to the women activists' digital behaviors who join SSI. Following this conception, this study attempts to understand how SSI's members use social media to communicate their environmental values and beliefs to the public to influence them. It also seeks to infer their strategy to change the public perspective on the environmental issues through interpreting the magnification of the verbal and visual posts on their walls. 


\section{Research Method}

The study's purpose is to observe social media's use to campaign and analyze the activists' posts' digital contents to understand their motivation to conserve river waters. It is also to identify their value systems and insights, which drive them to take action. The research paradigm develops from the notion of incorporating digital media into everyday life, which unfolds individuals' or groups' circulations, reimaginations, magnifications, deletions, translations, revisions, and the remaking of a range of cultural representations, experiences, and identities (Coleman 2010). It focuses on the community of SSI's individual and collective engagement with social media to explore how their social media posts reflect and shape their social practices, especially their idea of environmentalism.

Ethnography of the digital or virtual world, referring to the way to explore and investigate the individuals' practices within the realm of technology, develops from the diffusion of digital technologies into everyday life through the user-friendliness of smartphone and social media applications (Hine 2000). It is also a flexible method to study new and developing phenomena of the cultural life presented on digital platforms (Hjorth et al. 2017). Ethnography of the digital or virtual world also aims to understand human practices in a natural setting; however, the engagement process between the researchers and the study participants digitally mediated in their digital ecosystem platforms as a space to present their everyday practices. Quite similar to the ethnography paradigm, digital ethnography focuses on interpreting individuals' lived experiences in their digital world (KaurGill \& Dutta 2017). This method offers the researchers the possibility to participate and interact with the community members through digitally mediated communication. The intention is to interrogate the knowledge and the meaning of technology from the individuals' cultural practices through the texts and/or graphics they post on the digital media (Wijaya \& Nurmalia 2018). This study uses ethnography to understand the people's cultural practices in their digital world because the study's subject is SSI's culture in utilizing social media for their purposes.

This study focuses on understanding and the posting behavior as the grassroots women's cultural practices who join SSI. The data were taken from 1-30 April 2019, and its source is three social media platforms: Instagram, Facebook, and Twitter, which the SSI activists use to communicate their activities to the public. This study considers the three media platforms as the digital realm of the SSI women, in which they present their self-identity, make sense of themselves, and perform their social relationship (Kaur-Gill \& Dutta 2017). These three platforms are the sites that offer the space for the activists to express, construct and share their ideas, which hopefully could drive to collective action. Social media platforms' networking is essential to communicate their ideas and raise awareness of the public to be involved with their environmental movement.

The first step to obtaining the data is typing the keyword 'Srikandi Sungai' on Instagram, Twitter, and Facebook and scrutinizing the postings. The next step is making observations as to the posting activists' behavior on their social media and the interactions between the activists on the three platforms. The purpose of the observation is to understand the patterns and orders of their relations and behaviors. Attention to articulating their beliefs, routine practices, and state of existence on their social media illuminates their vernacular environmentalism culture. This study can draw their identities and the cyberspace structure's meaning from their digital activities of how, where, and why the activities matter through posting photos, videos, and comments. From their posting behaviors of how they communicate and respond to each other, through photos, videos, and comments, the researchers can understand how they use social media as the space to campaign goals of changing the perspective of the public concerning the need to maintain the cleanliness of the water rivers and the riverbanks.

Like ethnography, the relationship with the field in digital ethnography should be addressed either on obtrusive or unobtrusive observation and participation (Wijaya \& Nurmalia 2018). It also sometimes requires interaction and dialogues and actively participating with the users to understand the posting behaviors. Because the relationship between the researcher and the users is through the digital realm, which allows being anonymous in the engagement with the community members, the researchers' position is only lurking online, borrowing Kozinet's term (Kozinets 2016). As with any 
other community members who tend to be silent but to support, this study chooses only to observe their participation and engagement with each other within the digital realm. The intention to keep the researchers' anonymity is to prevent a shift in their posting behavior, which should naturally occur in their community.

\section{Results and Discussion}

In the pursuit to explore the significance of social media for environmental activists, this study analyzes the posting behavior of the activists in three different social media platforms: Instagram, Twitter, and Facebook and interprets the polarity of the posts, and categorizes them into specific themes from the similarities. The justification of doing such analysis derives from each platform's different characteristics, which generally need a specific analysis method. Scholars are interested in studying Twitter because it provides large and vivid comments, discussions, compliments, or arguments from people with various cultural, social, and religious backgrounds.

The massive tweets that people present create a hashtag as a unique characteristic of the communitydriven category to highlight a topic. Thus, scholars tend to analyze Twitter by measuring each hashtag's dataset and categorizing the information into sentiment analysis as positive, neutral, or negative expression (Wang et al. 2011). Compared to Twitter, Facebook is a closed platform because the posts' circulation is only for connected friends. With the platform's particular privacy settings, the public can only access the posts as managed by users. It makes Facebook not a subject for massive data analysis. However, some researchers have also conducted sentiment analysis to Facebook to determine the texts' polarity and the emoticons as signals of the intended sentiment (Vashisht \& Sangharsh Thakur 2014).

Social Network Sites (SNS), such as Facebook and Instagram, provide users a space to link individuals' networks. Such platforms are used as an alternative to face-face interaction in which users can maintain relations and ties, exchange numerous information, and for self-presentation (Ibrahim 2015). Facebook and Instagram provide all aspects needed for public displays of users' identity (Becker 2017). The graphic component dominant in these platforms encourages scholars to study the contents' explorative analysis and identify variables such as image types, common themes, and symbols. The tag accompanying the photos can be used to enhance the intention of the posts. Some scholars prefer to employ semiotic analysis to Instagram images to study the everyday activities presented online as visual culture.

The photography of everyday life has a social dimension - the meaning of the image decoded within shared values and a system of thought. Since the general screening to the three platforms is to know the number of the posts and how the networking of the SSI activists results in a small number of posts and comments, this study employs a qualitative approach to both the visual and verbal posts to understand the messages the environmental activists communicate to the public. The interpretation follows the social dimension of images of everyday life in Indonesian shared values and thought systems. Such interpretation choice entails the broad analysis of the sharing image functions for the environmental activists in Indonesia. It does not understand the transformation of environmental activists' campaigns from offline into online activism and the success achieved.

The growing discussions on social media as tools for activism mobilization focus on digital activisms' potential and limitations. Digital media researchers acknowledge social media's potentials in their role to challenge dominant discourses, raise awareness on specific issues, and the effectiveness of sharing personal stories (Kim 2017). However, it also raises the possibility of social media's power to transpose societal problems. They have found the visibility campaign by sharing images, videos, and text messages to raise consciousness and stimulate actions (Woods 2014).

Indonesia is the craziest nation on online social networking, reported by Sara Sidner on CNN (Lim 2015). Twitter and Facebook are the most popular social media users for fun posting and for generating social movements. As reported on CNN, some observers mention that social media 
encourages Indonesians to make meaning on democracy and freedom of speech (Lim 2015). Some posts on social media even prompt people to strike out against the injustice of the governmental system. Some cases are successful; however, others are not virally circular, making it difficult to measure their effects on the posts as social movements (Lim 2015).

In the case of environmental activism on digital media, since the mid-late 1990s, web-based environmental organizations and communities have been flourishing to stimulate interest in environmental issues. Focusing on the linking pattern of cyberspace's environmental network, researchers speculate cyberspace activism's implication on the emergence of the environmental movement on the ground. Problems and constraints that the activists face are in their limited access and influences on the environmental policymaking process, such as on what happens to Environmental Non-Governmental Organization (ENGO) in China. Thus, the activists utilize cyberspace's social networks as a mechanism to raise issues on the problems of the environmental laws and regulations (Sullivan \& Xie 2009). Other researchers are interested in interrogating the application of social media and new forms of digital activism. Their interests are understanding environmental activists' perspective to bring about action, from their concern on environmental degradation to directly engaging with conservation activities and environmental management. Some of them attempt to find out the linkage between online environmentalism and offline spaces of environmental activities (Büscher et al. 2017). Although their focuses are different, all researchers seem to have a similar interest in social media's implications toward the political ecology and their contribution to global conservation.

Various studies on the implication of social media to generate social movements in Indonesia have been conducted, with findings of the significance of social media on the dynamics of social movements, such as mobilization of direct action (Nugroho 2008); however, research still rarely focuses on how the social media can stimulate actions to conserve the environment. Scrutinizing the three most popular social media in Indonesia, Facebook, Twitter, and Instagram, there are many environmental hashtags and communities with deep concern to conserve the environment and participate in global environmentalism. SSI's activities on creating hashtags and forming environmental communities are attractive, leading to support from both the non-governmental and governmental institutions. Their posting behaviors initiate questions of their strategic uses of social media to mobilize societal actions to change the public perspective in looking at the environment, especially rivers. What messages do they want to send through their combination of posting videos, pictures, and texts?

Typing 'Srikandi Sungai Indonesia' on Instagram comes up \#srikandisungaiindonesia with only 18 public posts; all posts are pictures of brochures, workshops, and selfies, and some posts are short videos of their activities. On every picture they post, they articulate their activities and opinion of the importance of clean water rivers, which gain responses from other individuals and linked with other hashtags on environmentalism, such as \#worldoceansday, \#vitsea, \#kpppari, \#indonesianwomeninrivernetwork, \#beatplasticpollution, \#vitaminsea, \#savetheriver, \#kotatangguhbencana, and \#sekolahramahlingkungandananak. Some individuals write their memories of playing on the clean riverbank with the clean water river; however, most individuals express their activities' purposes.

In typing 'Sekolah Sungai Klaten' as one of the networks of \#srikandisungaiindonesia, it comes up with \#sekolahsungaiklaten with 40 public posts. Nine of the posts are videos of their activities on the clean rivers. Like \#srikandisungaiindonesia, the posts on \#sekolahsungaiklaten are pictures of the activities of the members cleaning the rivers and conducting fun activities along the green and clean riverbanks and the river streams. In every picture or video, they write their activities, such as spreading thousands of fish seed in the river, articulating their spirit to work hand in hand to clean rivers, and the need to sacrifice their time and energy, both to get rid of the pollutants and maintain the cleanliness of the water rivers. The hashtag \#srikandisungaiindonesia is also networked with other environmental communities, especially river environmental communities, such as the kaliuntu community, and linked with other hashtag activism the need to clean rivers. 


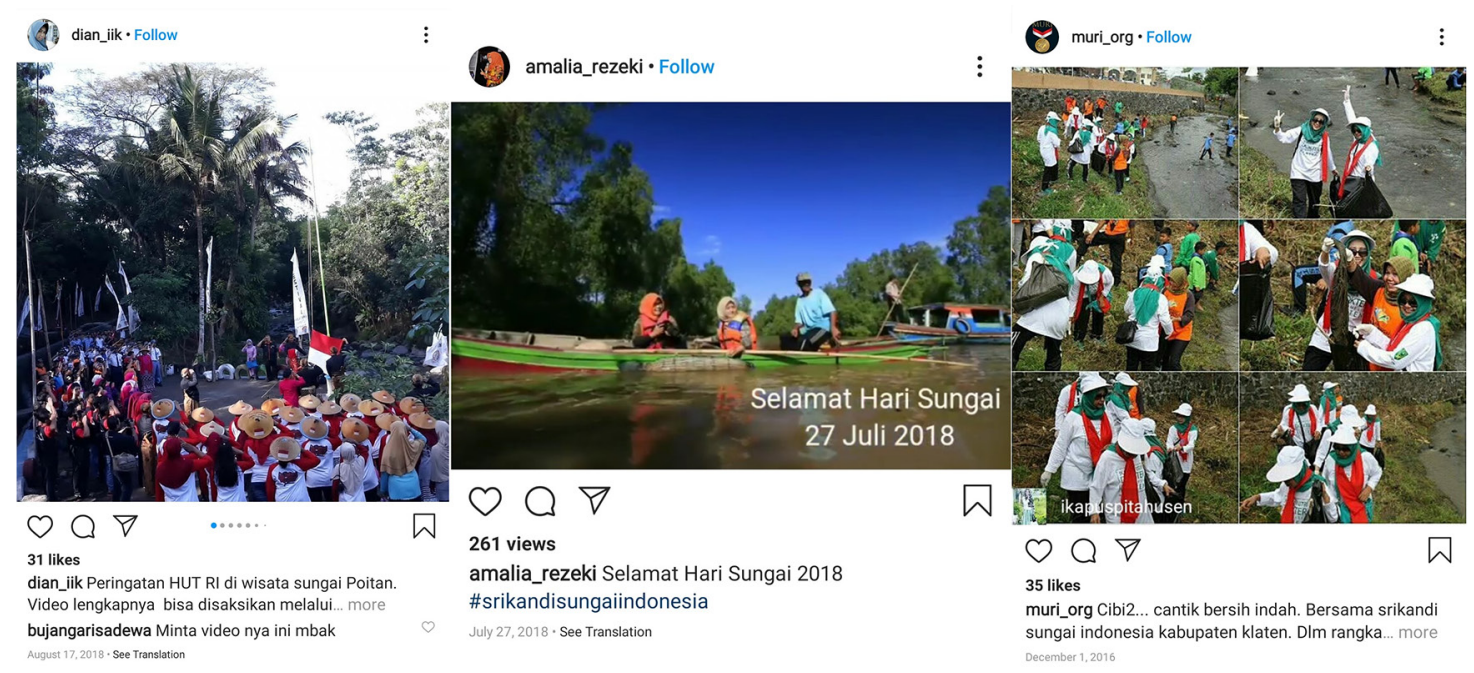

Figure 1.

The visual and verbal posts of the members of SSI in Instagram

Source: Instagram (2018)

Instagram is an image-focused social media platform; it functions to visualize everyday cultural practices mostly. The SSI activists also consider maximizing the function of photo-sharing as provided by Instagram to send messages about the need to look after rivers and its surrounding. In decoding the photos, three themes come up as symbol usages consisting of fun activities, children, women, and clean water rivers (Figure 1). The everyday activity of children performing the ceremony of flying the Indonesian flag, the outbound fun activities of some women, and cleaning a river send messages about the benefits of rivers and riverbanks' cleanliness. Within shared values and Indonesians' thought process, the clean rivers provide an exchange of both the formal activity of flying the Indonesian flag at the schoolyard and the fun with the extra-cost of outbound activity. These can be done only by looking after the cleanliness of rivers.

Scrutinizing every photographic and video post on their Instagram, not all posts gain responses or comments. The only post that gains 20 comments is the picture of the members' activity in a meeting for coordination between social media admin members on the riverbank Poitan. Accompanying its post is their statement that rivers' function has changed from a quiet and desolated place into a beautiful and lovely public sphere to conduct various activities. The comments arising from this post are from the other members who express their disappointment because they could not attend the meeting and who express their support to maintain their spirit to continue the activism. Although this research does not intend to look at the gender divide in social media activism, the research still identifies that the posts which attract comments mostly are not from the female activists or the leader of SSI but from the male activists who support the environmental activism. It seems that female activists are still quiet and only send their like as their support on Instagram.

Twitter redirects the words to @sekolahsungaiklaten, which has 133 followings and 613 followers. Account@sekolahsungaiklaten joined Twitter in June 2016. Since then, it has posted 359 photos and videos. The first posts are shown to the public that they have been networking with the local government of Central Java and the Klaten Regency, some environmental activists, and education institutions. The photos posted on Twitter have presented the clean rivers with some children playing and bathing along the streams from the beginning because the rivers look clean and the water looks clear, the photos do not negatively attract public reaction to comment on the children's activity in the rivers. Some photos show the green riverbanks; however, the ecology along the riverbanks are clean, free of debris, and set up like a park or playground. From all photos posted, interpretation derived is an attempt to change public perspectives on the idea of riverbanks in the past, which tended to be quiet and deserted.

Most photos are about conducting various activities along the riverbanks, including children playing and doing fun games. Since the river streams are clean and the ecology has been made as a safe and 
friendly public area for all people from different ages to conduct various activities, the messages sent are the attempt of@sekolahsungaiklaten to change public perspectives on the function of rivers and riverbanks into tourism area and the public sphere. Some photos show children's activities in the river, such as elementary school children spreading fish seed, some children sitting on car tires sliding along the river stream, and children bathing and swimming in the rivers. Other photos present the activities of people in collaboration with government institutions collecting garbage along the river stream. All photos posted show similar themes that the water river is clear and the ecology of the riverbanks is clean because people are responsible for the cleanliness of the water and the ecology of the river.

The SSI activists have also shared photos to campaign about an alternative function of a riverbank. All photos are the presentation of the activities of SSI (Figure 2). Wisata Panggang Village shows off the capture of their activity of the declaration of commitment of managing household waste. Yani Sumarno presents her visual records of the official confirmation of SSI in the Wedi Sub-district in Klaten Regency, while @sekolahsungaiklaten shares the images of collaborative activities of some parties in cleaning rivers; however, all photo sharing entails the activists' performativity rather than presenting their hard work of cleaning rivers. The images become just theatrical because they do not provide real activity, which shows the extra energy needed to change polluted rivers into environmental-friendly spaces for conducting many activities. When people used rivers to fish and irrigate the rice field, the photos of the informal and formal activities on the riverbank send a message of an alternative function riverbank; when people conserve rivers' ecology, rivers' function can be broadened. People can utilize rivers to generate benefits, such as creating an ecotourism village.

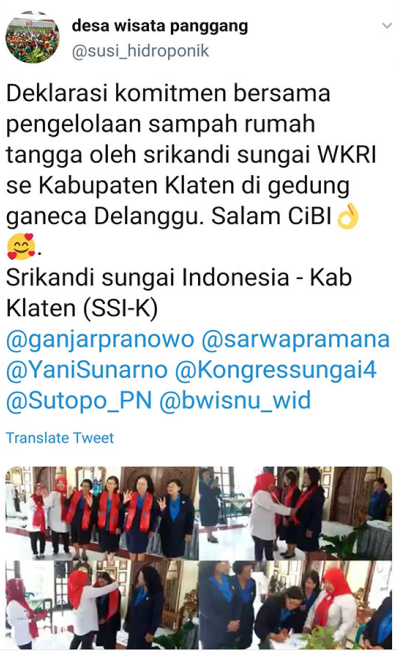

Figure 2.

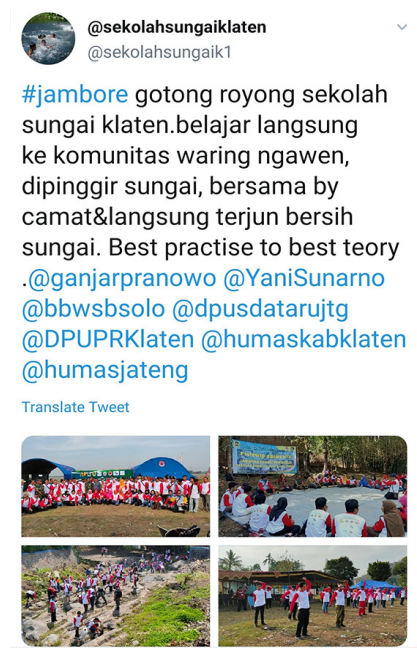

(6) Yanis Sunarno

Pengukuhan Srikandi Sungai Indonesia di Kalitengah Kec. Wedi, Klaten.

"Srikandi Sungai Indonesia, 100\%

Cinta Indonesia.

Srikandi Sungai Jawa Tengah, LUAR BIASA "

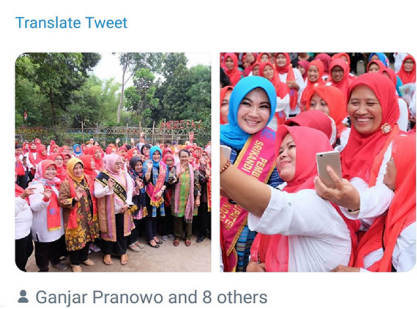

The tweets and the selfies of the SSI activists in Twitter

Source: Twitter (2018)

The photos posted seem promising to return the function of rivers as a source of life. It contrasts with the fact of some rivers in towns are polluted by people's irresponsible behaviors. Such as throwing away garbage to rivers. The river water on the photos is clean and assures the public that they can have clean water for their daily needs, whether for irrigating rice fields, watering plants, or fish plants. Meanwhile, the rivers' ecology provides messages that people have open public spaces to relax or conduct informal or formal activities. Thus, it seems@sekolahsungaiklaten communicates to the public that clean rivers mean a healthy life and soul.

Observing the verbal tweets, although most tweets are short, the verbal messages are to ask the public to participate in their activities. The words or expressions that they post are 1) with 3000 activists, communities, the Indonesian army, Indonesian police, students, SSI, 2) continuing to clean rivers and plants, to clean Klaten, 3) art festival along the river, local wisdom, 4) formal meeting, clean Klaten, 5 ) when the society move, everybody will move. Since the verbal posts are short, the images provide more vital messages. The function of the verbal posts is only to give information about the activities on the photos. 
Typing 'Srikandi Sungai Indonesia' on Facebook, Srikandi Sungai Indonesia-Klaten Regency (SSI-K) comes up with 162 members. The word SSI is the tag that serves as a marker of the environmentalists' community. With the specific tag, information of relevant posts, images, and videos can be obtained, allowing the analysis of the images' meaning. Most posts dominantly come from the leader of SSI-K, Susi; she shares many pictures of SSI-K's activities and invites the public to join the movement. Most pictures posted on their Facebook are their self-presentations during workshops, gaining responses from individuals as the governmental institutions' representatives. Susi shared photos of household waste management's economic benefits, and she campaigned through pictures posted on her Facebook account (Figure 3). She explained that by stopping throwing household waste into rivers, managing household waste and recycling, reducing and reusing it for growing hydroponic vegetables, women could get additional income as the target of her campaign. All images seem theatrical since cleaning rivers, managing household waste, and growing hydroponic vegetables are not sweat-free activities. The beauty shown in the images is the hard work product but is unfortunately not posted on her Facebook.

Similar to the posts on Instagram, the verbal posts are also short and only to provide information of the photos, such as the declaration of waste management, the inauguration of 1.000 members of SSI-K, declaration of household management, thankful expression to the community of hydroponics Klaten for joining every expo of SSI, and welcome to the earth day. Despite the number of photos posted by the head of SSI, there are not many other members' responses. When some comments do arise, most are only to say 'congratulation.'

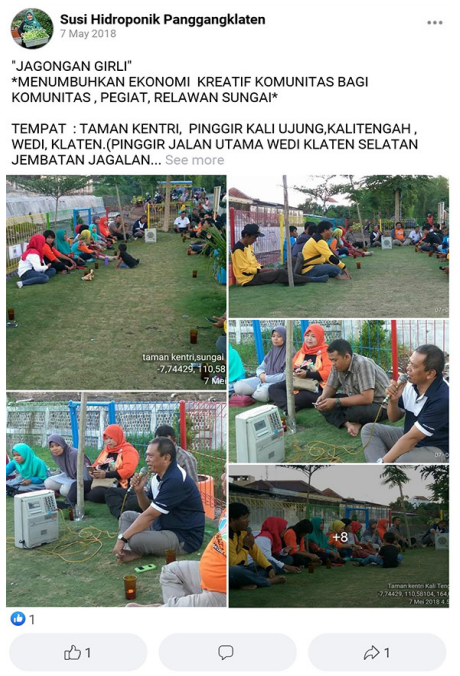

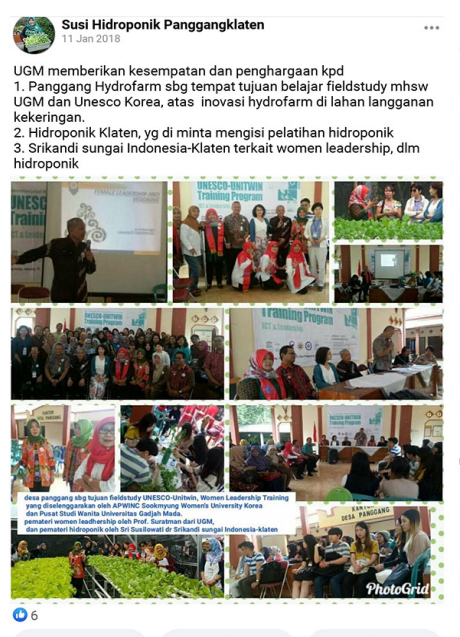

6

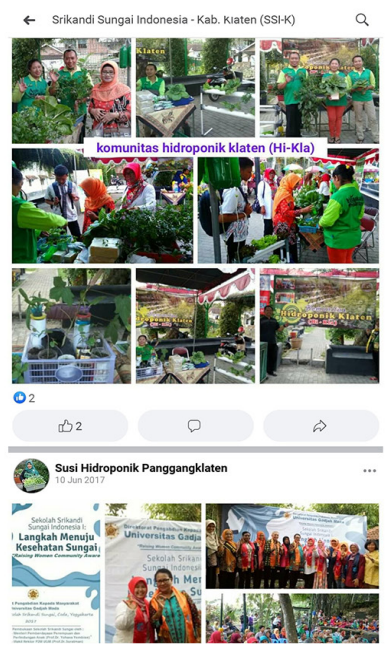

Figure 3.

The manifestation of the distinctive activities of environmentalists in Facebook Source: Facebook (2018)

Interpreting the posting behaviors as the cultural practices of Indonesian women, this study argues that environmental activism in this study in some way is not the extension of their domestic activities. With various postings of making people happy, especially children, and selfies of conducting workshops with many participants, the environmental activism for the members of SSI involves both the extensions of their domestic concerns of the need to have proper spheres for children to play and develop their creativity as well as their public participation to contribute a political ecology of the environment. Thus, their posting behaviors send messages of Indonesian women's identity to their fluidity to actively participate in domestic and the public spheres.

Scrutinizing the posts, mostly the pictures on the three social media platforms, the function of social media for the environmental activists, especially the head of the community, is to draw the attention of the public to the existence of the environmental community and its activities in campaigning for the need to protect the cleanliness of river water s and banks. By posting their pictures of their activities and their selfies with the influential governmental leaders, they magnify the activities as a successful environmental movement. They seem to say that their movement has been recognized and supported 
by both the local and national government. In this case, social media's function is to publicize the community's environmental actions, which lead them to get an award. Such finding is relevant to social media and environmental movements (Hawkins \& Silver 2017). For SSI's activists, social media's significance to the environmental movement is to attract the government's attention to support the movement. Correlating to the Indonesian context, especially the Javanese context, on the idea of power in Javanese culture as has been argued by Anderson (2006), the selfies with the head of the local government, either the local government of Central Java or Klaten Regency, are essential to share because it sends a message that the person posting the photos has a connection to influential persons who have political power in the nation. On another expression, the selfies display their pride and that those who send the photos are also important. Thus, their selfies can be interpreted as their attempt to attract followers because their activities are important and supported by the government.It is contrary to various environmental movements in other countries that are still conducted to raise the government's awareness as to the damage to the environment (Nulman \& Ozkula 2016) and as a mechanism to attract the government's attention to the importance to include environmental activists in the process of producing environmental regulations and laws (Sullivan \& Xie 2009). The self-presentation of the head of SSI signifies the government's recognition and support of the activities. Considering the number of offline environmental activists has increased to 1.000 people, the online environmental activists are only a few who actively post and share their activities and comments; however, the inactive members are not slacktivists who only click 'like' to support. It confirms the previous finding on the Indonesians' digital divides on their incorporation of digital technology in their everyday life.

\section{Conclusion}

Studying the posting behaviors of SSI's activists as an environmental movement on the three social media platforms confirms the previous studies regarding social media's significant roles in developing the environmental movement by utilizing the potential of spreading information on different platforms. This study finds that the activists use social media to communicate their existence and their activities to attract the public to join the community and the movement. The combination of images, videos, and texts on their posts are selectively chosen functions to persuade the public to support their environmental activism through sending messages of the benefits of having clean environments as public spheres to conduct various fun activities. With many postings of people of different ages doing rowing and water-skiing and the happiness of children playing with clean water and doing activities on clean and green riverbanks, they subconsciously persuade the public to undertake recreations physically and mentally healthy. Thus, social media's networking functions are maximally utilized for self-presentation of their activities and their achievements; however, this movement does not attract many followers on their walls. Although the community members have reached 1.000 to work hand-in-hand to clean the rivers and create green parks on the riverbanks, they tend to be passive on their social media. Only the community head actively posts their activities and attempts to change the public's perspective to see rivers differently.

It also shows that the environmental activist women use social media to communicate their activities rather than maximizing its function to campaign to change the public perspective and attitude concerning the need to take care of the river water and riverbanks. Thus, the study argues that the women activists continue to adopt the dominant Indonesian patterns and social media use orders. Social media's function in developing political messages concerning environmentalism is still only looking like a space for selfies rather than developing a political message concerning environmentalism.

This study confirms the Indonesians' digital divide on their incorporation of digital technology into their everyday lives. Although the general public says that social media is a women's sphere, male environmental activists are more active in giving comments and joining the conversation rather than female activists in environmentalism. It raises another question as to whether the digital divide is caused by gender difference or other aspects, such as internet access, the activists' geography, or other activities that could hinder their digitally active participation. 


\section{References}

Anderson BRO'G (2006) Language and Power: Exploring Political Culture in Indonesia. United Kingdom: Equinox Publishing.

Badan Pusat Statistik (2018) Statistik Indonesia 2018. Jakarta: Badan Pusat Statistik.

Becker D (2017) Instagram as a Potential Platform for Alternative Visual Culture in South Africa. In: Bunce et al. (eds). Africa's Media Image in the $21^{\text {st }}$ Century: From the "Heart of Darkness" to "Africa Rising." London: Routledge.

Bennett WL (2004) Communicating Global Activism: Strengths and Vulnerabilities of Networked Politics. In: van de Donk et al. (eds). Cyberprotest, New Media, Citizens and Social Movement. London: Routledge.

Blocker T \& Eckberg D (1989) Environmental issues as women's issues: General concerns and local hazards. Social Science Quarterly 70 (3):586-593.

Braman S (2002) Defining Tactical Media: An Historical Overview. In: Abrash B \& Ginsburg F (eds). Tactical Media: The Virtual Casebook. NY: NYU.

Breton M (1998) Women Pioneers for the Environment. Boston: Northeastern University Press.

Büscher B (2014) Nature 2.0: Exploring and theorizing the links between new media and nature conservation. New Media and Society 18 (5):1-18. https://doi.org/10.1177\%2F146144481 4545841.

Büscher B, Koot S, \& Nelson IL (2017) Introduction. Nature 2.0: New media, online activism and the cyberpolitics of environmental conservation. Geoforum 79 (2017):111-113. https://doi. org/10.1016/j.geoforum.2016.12.001.

Castells M (2013) Networks of Outrage and Hope: Social Movements in the Internet Age. Hoboken, NJ: John Wiley \& Sons.

Coleman EG (2010) Ethnographic approaches to digital media. Annual Review of Anthropology 39 (2010):487-505. https://doi.org/10.1146/annurev.anthro.012809.104945.

Dalsgaard S (2016) The ethnographic use of Facebook in everyday life. Anthropological Forum 26 (1):96-114. https://doi.org/10.1080/00664677.2016.1148011.

Facebook (2018) Srikandi Sungai Indonesia-Kab. Klaten. [Accessed 30 April 2019]. https://www. facebook.com/groups/ 1322136361169828/.

Gerbaudo P (2012) Tweets and the Streets: Social Media and Contemporary Activism. London: Pluto Press.

Gurstein M (2007) What is Community Informatics (and Why Does it Matter)? Milan, Italy: Polimetrica.

Hawkins R \& Silver JJ (2017) From selfie to \#sealfie: Nature 2.0 and the digital cultural politics of an internationally contested resource. Geoforum 79 (2017):114-123. https://doi.org/10.1016/j. geoforum.2016.06.019.

Hemmi A \& Crowther J (2013) Learning environmental activism through social networking sites? Concept 4 (1):1-7.

Hine C (2000) Virtual Ethnography. London: SAGE Publications Ltd.

Hjorth L, Horst H, Galloway A, \& Bell G (eds) (2017) The Routledge Companion to Digital Ethnography. New York: Routledge.

Ibrahim J (2015) Instagramming life: Banal imaging and the poetics of the everyday. Journal of Media Practice 16 (1):42-54. https://doi.org/10.1080/14682753.2015.1015800.

Instagram (2018) Srikandi Sungai Indonesia. [Accessed 30 April 2019]. https://www.instagram.com/ explore/tags/srikandisungai indonesia/?hl=e.

Jenkins H (2006) Convergence Culture: Where Old and New Media Collide. NY: NYU Press.

Joyce M (2010) Digital Activism Decoded: The New Mechanics of Change. NY: International Debate Education Association. 
Kaur-Gill S \& Dutta MJ (2017) Digital Ethnography. In: Matthes J (ed). The International Encyclopedia of Communication Research Methods. NJ: John Wiley \& Sons.

Keeble L \& Loader BB (eds) (2001) Community Informatics: Shaping Computer-Mediated Social Relations. London: Routledge.

Kim J (2017) \#iamafeminist as the "mother tag": Feminist identification and activism against misogyny on Twitter in South Korea. Feminist Media Studies 17 (5):804-820. https://doi.or g/10.1080/14680777.2017.1283343.

Kozinets RV (2016) Netnography. In: Ritzer G (ed). The Blackwell Encyclopedia of Sociology. NJ: John Wiley \& Sons.

Leyva R (2018) Exploring UK millennials' social media consumption patterns and participation in elections, activism, and 'slacktivism'. Social Science Computer Review 35 (4):1-18. https:// doi.org/10.1177/0894439316655738.

Lievrouw LA (2011) Alternative and Activist New Media. Cambridge: Polity Press.

Lim M (2015) Many licks but little sticks: Social media activism in Indonesia. Journal of Contemporary Asia 43 (4):636-657. https://doi.org/10.1080/00472336.2013.769386.

Mohai P(1992) Men, women, and the environment: An examination of the gender gap in environmental concern and activism. Society \& Natural Resources: An International Journal 5 (1):1-19. https://doi.org/10.1080/08941929209380772.

Murthy D (2013) Twitter Social Communication in the Twitter Age. Malden: Polity Press.

Nugroho Y (2008) Adopting technology, transforming society: The internet and the reshaping of civil society activism in Indonesia. International Journal of Emerging Technologies and Society $6(2): 77-105$.

Nulman E \& Ozkula SM (2016) Environmental nongovernmental organizations' digital media practices toward environmental sustainability and implications for informational governance. Current Opinion in Environmental Sustainability 18 (2016):10-16. https://doi.org/10.1016/j. cosust.2015.04.004.

Pertana PR (2017) UGM resmikan Sekolah Srikandi Sungai Indonesia 1. Tribunjogja.com, 10 June. [Accessed 1 May 2020] https://jogja.tribunnews.com/2017/06/10/ugm-resmikan-sekolahsrikandi-sungai-indonesia-1.

Riles A (2001) The Network Inside Out. Ann Arbor: The University of Michigan Press.

Sahana M (2017) Sekolah Srikandi Sungai, partisipasi perempuan lestarikan lingkungan dan sungai, VOA Indonesia, 12 June. [Accessed 1 May 2020]. https:/www.voaindonesia.com/a/sekolahsrikandi-sungai-partisipasi-perempuan-lestarikan-lingkungan-dan-sungai/3896606.html.

Segerberg A \& Bennett WL (2011) Social media and the organization of collective action: Using Twitter to explore the ecologies of two climate change protests. The Communication Review 14 (3):197-215. https://doi.org/10.1080/10714421.2011.597250.

Serafinelli E (2018) Digital Life on Instagram: New Social Communication of Photography. Bingley, WA: Emerald Publishing.

Stolterman E (2001) Creating Community in Conspiracy with the Enemy. In: Keeble L \& Loader BB (eds). Community Informatics: Shaping Computer-mediated Social Relations. London: Routledge.

Strapko N, Hempel L, MacIlroy K, \& Smith K (2016) Gender differences in environmental concern: Reevaluating gender socialization. Society \& Natural Resources 29 (9):1015-1031. https:// doi.org/10.1080/08941920.2016.1138563.

Sullivan J \& Xei L (2009) Environmental activism, social networks and the internet. The China Quarterly 198 (2009):422-432.

Twitter (2018) Sekolah Sungai Klaten. [Accessed 30 April 2019]. https://twitter.com/sekolahsungaik1. Van Leeuwen T \& Jewitt C (2004) The Handbook of Visual Analysis. London: Sage. 
Vashisht G \& Thakur S (2014) Facebook as a corpus for emoticons-based sentiment analysis. International Journal of Emerging Technology and Advanced Engineering 4 (5):904-908.

Vivienne S (2016) Digital Identity and Everyday Activism. London: Palgrave Macmillan.

Wang X, Wei F, Liu X, Zhou M, \& Zhang M (2011) Topic sentiment analysis in Twitter: A graph-based hashtag sentiment classification approach. In: Proceedings of the $20^{\text {th }}$ ACM International Conference on Information and Knowledge Management.

Wellman B (2001) Physical Place and Cyberplace: The Rise of Networked Individualism. In: Keeble L \& Loader BB (eds). Community Informatics: Shaping Computer-mediated Social Relations. London: Routledge.

Wijaya SW \& Nurmalia (2018) Investigating user experience with digital ethnography approach: Principles and guidelines. In: $10^{\text {th }}$ International Conference on Information Technology and Electrical Engineering: Smart Technology for Better Society.

Woods HS (2014) Anonymous, Steubenville, and the politics of visibility: Questions of virality and exposure in the case of \#OPRollRedRoll and \#OccupySteubenville. Feminist Media Studies 14 (6):1096-1098. https://doi.org/10.1080/14680777.2014.975439.

Zelezny L \& Bailey M (2006) A call for women to lead a different environmental movement. Organization \& Environment 19 (1):103-109. https://doi.org/10.1177/1086026605285588.

Zelezny L, Chua P, \& Aldrich C (2000) Elaborating on gender differences in environmentalism. Journal of Social Issues 56 (3):443-457. https://doi.org/10.1111/0022-4537.00177. 